\title{
Professional, scientific, and social life of cardiology specialists
}

\author{
Gonul Aciksari $^{\mathrm{a}, *}$, Mehdi Zoghi ${ }^{\mathrm{b}}$, on behalf of the CAS-TR group ${ }^{1}$ \\ a Istanbul Medeniyet University Goztepe Research and Training Hospital, Cardiology Department, Istanbul, Turkey \\ b Ege University, Cardiology Department, Izmir, Turkey
}

\section{A R T I C L E I N F O}

\section{Article history:}

Received 10 September 2017

Received in revised form 13 September 2017

Accepted 14 September 2017

Available online 18 September 2017

\section{Keywords:}

Cardiology specialty

Social and scientific life

Questionnaire

\begin{abstract}
A B S T R A C T
A questionnaire-based study was designed to assess the perceptions of cardiology specialists in Turkey regarding the working conditions, scientific and social life, as well as cardiology training. This transverse cross-sectional study was carried out with the voluntary participation of 143 cardiology specialist ( $81.4 \%$, male). A questionnaire consisting of 34 questions was used to evaluate professional and scientific lives as well as the social activity level of the participants. More than half of the participants (51\%) had a working experience of $>10$ years, and those with a preference for the fields of general cardiology, interventional cardiology, image-based cardiology, and arrhythmia represented $78.3 \%, 59.4 \%, 30.8 \%$, and $10.5 \%$ of the study population, respectively. $53.1 \%$ of the cardiology specialists surveyed reported having participated in international multi-center trials as a co-investigator, and $80.5 \%$ reported being in the author list of publications included in Science Citation Index (SCI), SCI expanded, Social Science Citation Index (SSCI), and Arts and Humanities Citation Index (AHCI). 70\% of the cardiology specialists included in the study reported that they could spend adequate time on social activities.
\end{abstract}

(c) 2017 The Society of Cardiovascular Academy. Production and hosting by Elsevier B.V. All rights reserved. This is an open access article under the CC BY-NC-ND license (http://creativecommons.org/licenses/by-nc-nd/4.0/).

\section{Introduction}

Cardiovascular Disorders (CVD) is the leading cause of death in industrialized countries. According to the 2002 data of World Health Organization (WHO), approximately 17 million individuals died of cardiovascular disease, and of these deaths 7.2 million were due to

\footnotetext{
* Corresponding author.

E-mail address: drgonulkutlu@hotmail.com (G. Aciksari).

1 Collaborates (142): Abdullah Özçelik, Abdurrahman Akyüz, Abdülmelik Yıldız, Adnan Doğan, Ahmet Erseçgin, Ahmet Göktuğ Ertem, Dr. Ahmet Haki Türkdemir, Ahmet Keser, Ahmet Temiz, Ali Kemal Çabuk, Arif Süner, Aykan Çelik, Bahadır Kırılmaz, Barış Buğan, Bayram Arslan, Burak Açar, Burak Sezenöz, Burcu Yağmur, Can Özkan, Cegerğun Polat, Celal Kilit, Cemal Köseoğlu, Cenk Ekmekçi, Cihan Aydın, Çağdaş Arslan, Çağrı Yayla, Çiğdem Koca Tarı, Doğaç Çağlar Gürbüz, Emrah Kaya, Emre Demir, Erkan Borazan, Ersin Çağrı, Esra Kaya, Eyüp Avcı, Fikret Keleș, Fuat Başanalan, Fulya Avcı Demir, Göksel Çağırcı, Gülsüm Meral Yılmaz, Güney Sarıoğlu, Hakan Ulupınar, Hande Oktay Türeli, Hasan Ali Gümrükçüoğlu, Hasan Güngör, Hasan Kaya, Hasan Kudat, Hașim Mutlu, Hatice Kemal, Hayati Eren, Hazar Harbalıŏlu, İbrahim Ersoy, İsmail Ünğan, Kaan Okyay, Kamil Tülüce, Khayal Mirzayev, Kutay Vurgun, Lale Dinç Asarcıklı, Lütfü Bekar, Mehmet Baran Karataș, Mehmet Hayri Alıcı, Mehmet Kıș, Mehmet Özgeyik, Meltem Özaydın, Murat Akçay, Murat Esin, Murat Kucukukur, Murat Samsa, Musa Bulut, Mustafa Beğenç Taşcanov, Mustafa Beyazıt Alkan, Mustafa Köklü, Mustafa Oğuz Varol, Mustafa Yenerçağ, Mustafa Yurtdaş, Necmettin Korucuk, Nermin Bayar, Oğuzhan Çelik, Oktay Ergene, Onur Akhan, Osman Karaarslan, Ömer Çelik, Özcan Örsçelik, Özcan Vuran, Özgen Şafak, Özgül Yıldız, Özlem Seçen, Pınar Yağcioğlu, Refik Karakaya, Rufet Memmedov, Salih Kılıç, Sara Çetin Şanlıalp, Seçkin Dereli, Sefa Ünal, Selcen Yakar Tülüce, Selvi Coşar Öztaş, Serdar Biçeroğlu, Serhat Günlü, Serhat Karadavut, Serhat Sığırcı, Songül Usalp, Suat Demirkiran, Sahin Topuz, Senol Tayyar, Tarık Yıldırım, Turgut Uygun, Uğur Kocabaș, Uğur Önsel Türk, Umut Kocabaş, Ümit Yüksek, Ünal Öztürk, Veysel Oktay, Veysel Tosun, Volkan Emren, Yavuzer Koza, Yeliz Sökmen, Yeşim Hoşcan, Yiğit Çanga, Yusuf Yılmaz, Zafer Yalım. Peer review under responsibility of The Society of Cardiovascular Academy.
}

coronary heart disease (CHD). ${ }^{1}$ In a study from Turkey conducted in 1990, the prevalence of CHD was $4.1 \%$ and $3.5 \%$ among men and women, respectively. ${ }^{2}$ The 5 -year follow-up report by the same researchers showed that the death rate due to CHD was 4.3/1000 and $4.0 / 1000$ in men and women, respectively. Based on current population estimations, it may be projected that there are approximately 1.5 million individuals with coronary artery disease in our country. Accordingly, each year $>100,000$ new cases of coronary artery disease are diagnosed, who subsequently require healthcare services from the national health system. Based on the data issued by the National Statistics Agency, it can be argued that the relative contribution of cardiovascular diseases to total mortality is progressively increasing, with cardiovascular diseases representing the major cause of mortality responsible for $40 \%, 45 \%$, and $40 \%$ of all deaths in years 1989,1993 , and 2000, respectively. ${ }^{3}$ It is evident from these figures that the impact of CHD on total mortality in Turkey is similar to countries where CVD is considered a public health priority. The professional life conditions and the availability of adequately interventional cardiology units bear high significance for the practicing cardiology specialists who are actively involved both in the primary and secondary prevention of cardiovascular diseases. In this questionnaire-based study, our objective was to assess the abovementioned factors among a group of cardiology specialists.

\section{Methods}

This cross-sectional study was carried out between March 2017 and June 2017, with the participation of cardiology specialists $(n=143)$ from Turkey. A 34-item questionnaire was used to assess the 
professional, scientific, and social life of the participants. The questionnaire included both open- and close-ended questions that gathered information on the duration of work, conditions of work, night shifts, number of patients currently followed-up, relative proportion of imaging and invasive procedures in the total workload as well as the availability of adequately equipped cardiology laboratories, frequency of attendance to scientific meetings and studies, social life etc. The questionnaire was sent to the participants via e-mailing, and was completed online. All participating physicians provided consent for the publication of data for research purposes. The questionnaires were completed by the participants over a 3-month period. For all statistical analyses, IBM SPSS version 21.0 was used (SPSS Inc., Chicago, IL, USA). Categorical variables were compared using chi-square or Fisher's exact test.

\section{Results}

\section{Demographical and professional characteristics}

The participants consisted of cardiology specialists currently employed in university hospitals (25.3\%), private hospitals (12.6\%), and state and research/training hospitals (62.2\%) across Turkey. Most specialists $(85.3 \%)$ were older than 30 years of age, and those with a working experience of $>10$ years comprised $73 \%$ of the cohort. Again, of the overall group, $25.2 \%$ were academicians, $14 \%$ were research associates/residents, and $60.8 \%$ were employed as specialists (Table 1). Majority of the physicians were practicing in the field of general cardiology (78.3\%), with $30 \%$ and $59.4 \%$ being more actively involved in imaging and invasive cardiology services, respectively. Those focusing on arrhythmia, ablation therapy, and EPS comprised only $10 \%$ of the participants. Cardiology training in Turkey was considered inadequate by $61.5 \%$ of these specialists, while $38.5 \%$ had the opposite view. Also, $86 \%$ reported that they considered sub-specialty training necessary for a number of areas in cardiology such as arrhythmias, imaging, or intervention.

\section{Patient follow-up load}

Of the all cardiology specialists included in our survey, 74\% reported seeing $>100$ outpatients per week, and $73 \%$ reported provision of

Table 1

Personnel and business characteristics of cardiologists.

\begin{tabular}{|c|c|c|c|}
\hline & & $\mathrm{n}$ & $\%$ \\
\hline \multirow[t]{2}{*}{ Sex } & Female & 26 & 18.8 \\
\hline & Male & 117 & 81.2 \\
\hline \multirow[t]{2}{*}{ Age } & $<30$ & 21 & 14.7 \\
\hline & $>30$ & 122 & 85.3 \\
\hline \multirow{3}{*}{ Academic title } & Resident & 20 & 14 \\
\hline & Physician & 87 & 60.8 \\
\hline & Lecturer in university & 45 & 25.2 \\
\hline \multirow{3}{*}{ Work experience (year) } & $<5$ & 18 & 13.6 \\
\hline & $5-10$ & 52 & 36.4 \\
\hline & $>10$ & 73 & 51 \\
\hline \multirow[t]{3}{*}{ Hospital/institution } & Private hospital & 18 & 13.6 \\
\hline & $\begin{array}{l}\text { MoH State Hospital, MoH Research and } \\
\text { Training Hospital }\end{array}$ & 69 & 62.3 \\
\hline & University & 36 & 25.1 \\
\hline \multirow[t]{4}{*}{ Night shifts (per month) } & None & 24 & 17 \\
\hline & $<5$ & 67 & 46 \\
\hline & $6-10$ & 33 & 23 \\
\hline & $>10$ & 20 & 14 \\
\hline \multirow{4}{*}{$\begin{array}{l}\text { Number of outpatients } \\
\text { (per week) }\end{array}$} & $<10$ & 3 & 2 \\
\hline & $10-50$ & 17 & 12 \\
\hline & $51-100$ & 17 & 12 \\
\hline & $>100$ & 106 & 74 \\
\hline \multirow{3}{*}{$\begin{array}{l}\text { Number of inpatients } \\
\text { (per week) }\end{array}$} & $<10$ & 59 & 41 \\
\hline & $10-30$ & 46 & 32 \\
\hline & $>30$ & 38 & 27 \\
\hline
\end{tabular}

Total $143 / 100$ specialist services for $<30$ hospitalized patients per week. Most of the participants $(46.1 \%)$ reported 5 or less night shifts per month, while $14 \%$ had more than or equal to 10 night shifts per month, and $14 \%$ had no night shifts.

\section{Laboratory practices}

The $73.4 \%$ of the participants reported performing $>50$ Transthoracic Echocardiography (TTE) procedures per week, while $65 \%$ performed $<5$ Transesophageal Echocardiography (TEE) procedures per week. With regard to invasive procedures, $74.1 \%$ of the physicians reported performing Coronary Angiography (CAG)/PCI, while 16.8\% were employed in facilities with no coronary angiography laboratory. Electrophysiological studies (EPS) and ablation facilities were available in their facility in $46.6 \%$ of the cases. Only $9.1 \%$ of the cardiology specialists included in this study reported performing EPS and ablation, while approximately $50 \%$ performed pacemaker, Intra-cardiac Defibrillator (ICD), and Cardiac Re-synchronization (CRT) procedures (Table 2). Trans-catheter aortic valve implantation (TAVI) was undertaken in $43.6 \%$ of the health facilities in which the participants were employed.

\section{Participation to scientific meetings, research and scientific publishing}

Of the cardiology specialists participating in the survey, $53.1 \%$ reported a role as a co-investigator in international multi-center studies, with $80.5 \%$ listed as an author in publications cited in Science Citation Index and 78\% reported membership in at least one international society (Table 3).

\section{Participation to social activities}

Seventy percent of the cardiologists reported reading at least one non-medical book per month, attending at least one social activity (going to a movie, theater, or concert etc.) per month, and $52.5 \%$ exercised at least for $30 \mathrm{~min}$ for at least one day per week. Proportion of cardiologists exercising for $30 \mathrm{~min}$ on 5 days of the week as

Table 2

Laboratory practices participation rates of cardiologists.

\begin{tabular}{lll}
\hline & $\mathrm{n}(143)$ & $\%(100)$ \\
\hline $\begin{array}{l}\text { Echocardiography } \\
\text { None }\end{array}$ & 4 & \\
$<50$ & 35 & 2.8 \\
$\quad>50$ & 105 & 23.8 \\
TEE & & 73.4 \\
None & 45 & \\
$<5$ & 65 & 31.4 \\
$5-10$ & 19 & 45.4 \\
$10-30$ & 10 & 13.2 \\
$>30$ & 4 & 7.2 \\
Interventional therapy (PTCA + stent) & & 2.8 \\
None & 37 & \\
$<5$ & 14 & 26 \\
$5-10$ & 46 & 10 \\
$10-30$ & 34 & 32 \\
$>30$ & 12 & 23.7 \\
Pacemaker & & 8.3 \\
None & 68 & \\
$<5$ & 45 & 47.5 \\
$5-10$ & 22 & 31.5 \\
$10-30$ & 6 & 15.4 \\
$>30$ & 2 & 4.2 \\
ICD/CRT & & 1.4 \\
None & 79 & \\
$<5$ & 37 & 55.2 \\
$5-10$ & 21 & 25.9 \\
$10-30$ & 4 & 14.7 \\
$>30$ & 2 & 2.8 \\
\hline
\end{tabular}

CRT - cardiac resynchronization therapy, ICD - implantable cardioverter defibrillator, TEE -transesophageal echocardiography, 
Table 3

Scientific life of cardiologists

\begin{tabular}{|c|c|c|}
\hline & n (143) & $\%(100)$ \\
\hline \multicolumn{3}{|c|}{ Publications within SCI, SCI expanded, SSCI and AHCI journals } \\
\hline None & 26.8 & 19.5 \\
\hline$<5$ & 43 & 30.1 \\
\hline $5-10$ & 22 & 15.4 \\
\hline $10-20$ & 14 & 9.8 \\
\hline $20-30$ & 12 & 8.4 \\
\hline$>30$ & 24 & 16.8 \\
\hline \multicolumn{3}{|c|}{ Panelist in national congress } \\
\hline None & 67 & 46.8 \\
\hline$<5$ & 75 & 52.5 \\
\hline $5-10$ & 1 & 0.7 \\
\hline$>10$ & 0 & 0 \\
\hline \multicolumn{3}{|c|}{ Panelist in international congress } \\
\hline None & 123 & 86 \\
\hline$<5$ & 20 & 14 \\
\hline $5-10$ & 0 & 0 \\
\hline$>10$ & 0 & 0 \\
\hline \multicolumn{3}{|c|}{ Report in national congress } \\
\hline None & 36 & 25.1 \\
\hline$<5$ & 89 & 62.2 \\
\hline $5-10$ & 11 & 7.7 \\
\hline$>10$ & 7 & 5 \\
\hline \multicolumn{3}{|c|}{ Report in international congress } \\
\hline None & 86 & 60.1 \\
\hline$<5$ & 53 & 37.1 \\
\hline $5-10$ & 2 & 1.4 \\
\hline$>10$ & 2 & 1.4 \\
\hline \multicolumn{3}{|c|}{ Participation in international association } \\
\hline None & 31 & 21.7 \\
\hline$<3$ & 96 & 67.1 \\
\hline $3-5$ & 12 & 8.4 \\
\hline$>5$ & 4 & 2.8 \\
\hline \multicolumn{3}{|c|}{ Referee in scientific journal } \\
\hline None & 89 & 62.2 \\
\hline$<3$ & 35 & 24.5 \\
\hline $3-5$ & 10 & 7 \\
\hline$>5$ & 9 & 6.3 \\
\hline \multicolumn{3}{|c|}{ Participation in national research } \\
\hline None & 37 & 25.9 \\
\hline$<4$ & 82 & 57.3 \\
\hline$>4$ & 24 & 16.9 \\
\hline \multicolumn{3}{|c|}{ Participation in international research } \\
\hline None & 67 & 46.8 \\
\hline$<4$ & 68 & 47.6 \\
\hline$>4$ & 8 & 5.6 \\
\hline
\end{tabular}

recommended by the 2016 European Cardiology Society, Cardiovascular Protection Guidelines was only around 9\%.

\section{Discussion}

To the best of our knowledge, this survey represents the first study in Turkey encompassing a wide range of physicians in the field of cardiology from specialists to residents, research fellows, and academicians and examining their working conditions as well as scientific and social lives using a questionnaire based design. The questionnaires were sent by e-mail. Rates of positive response from e-mail or mail based medical studies without face-to-face contact are very low. ${ }^{4-6}$ Consistent with these previous observations, only a certain proportion of the cardiologists completed and returned the questionnaire. $85.3 \%$ of the participants were 30 years or older, and only $3.5 \%$ were at least 50 years of age; $13.6 \%$ had a short working experience ( $<5$ years). In a previous study from the United States of America (USA) approximately $40 \%$ of the general cardiologists were around 55 years of age. ${ }^{7}$ The higher average age reported among cardiologist from the USA may be accounted for by a number of factors including the requirement for a 6-year training period to qualify as a cardiologist and importance placed upon minimum work experience. Of our participant cardiologists, $18.8 \%$ were female, similar to the figures reported from the USA where only $12 \%$ and $10 \%$ of general and interventional cardiologists respectively consisted of female physicians. ${ }^{8}$ Most female physicians avoid fluoroscopic procedures during pregnancy, while such interventions are a prerequisite for right and left sided cardiac catheterization and diagnostic coronary angiography. Occupational exposure to radiation is a great source of concern during training and professional career among female cardiologists. ${ }^{9}$ This may have an impact on the preference of female physicians for cardiology training. Also, several other factors in the USA have been reported to affect the lower preference for cardiology training among female physicians including the duration of training required for achieving clinical competency, compensation fees, work-life balance, and family responsibility. ${ }^{8}$ Studies specifically examining such potential factors for lesser preference of cardiology specialty among female physicians are warranted in our country. The increase observed in the prevalence of coronary artery disease as well as in the number of therapeutic options for their treatment have allowed rapid advances in the field of invasive cardiology. This fact is also reflected in the practice of cardiology in our country. While such interventions could be undertaken in only 25 centers with only 93 physicians trained in invasive cardiology in 1992, the number of centers with invasive cardiology facilities has risen to 60 by the year $2000 .{ }^{11}$ In our study, $83.2 \%$ of the participating physicians reported that they do not have a coronary angiography laboratory at their place of employment. The $74 \%$ of the cardiology specialists reported performing coronary angiography and invasive procedures (PTCA and stenting). In 1993, permanent pacemakers were implanted in 1100 cases, and majority of the pacemakers implanted consisted of single-chamber products, rather than doublechamber ones. ${ }^{10}$ In the current study, monthly number of pacemaker implantation and CRT procedures reported by the physicians were comparable, with some cardiologists performing $>30$ procedures per month.

The required duration of cardiology residency in Turkey is 2 years for physicians who have completed their internal medicine training, and 4 years for general physicians. After completion of this period of time, cardiologists are granted the legal rights to perform invasive cardiac procedures. In other countries, the requirements include 1 or 2 years of additional invasive training plus adequate number of invasive procedures performed. ${ }^{10}$ Of our participants, $61.5 \%$ viewed the cardiology training in Turkey inadequate, while $38.5 \%$ considered it adequate. Also, $86 \%$ believed that sub-specialty training should be implemented for areas such as arrhythmia, imaging, or interventions. Currently there are no such regulations in our country, and changes in relevant legislations are required.

In a 2011 study involving only cardiology residents, only $9.1 \%$ of the residents were included in the author list of publications in $\mathrm{SCI}$, and $32.6 \%$ participated as an investigator in international trials. In addition, only $12.9 \%$ of the residents reported presentation in a national congress. ${ }^{12}$ In our study, proportion of cardiologist in the author list of studies published in the context of SCI, SCI expanded, SSCI, and AHCI were $73.2 \%$, while proportion of panelists in national congresses was $59.5 \%$, and $74.1 \%$ reported having participated in international trials as co-investigators.

In the same study, only $32.9 \%$ of the cardiology residents reported spending adequate time on social activities, ${ }^{12}$ as compared to $70 \%$ in our cardiologist participants (Fig. 1). In addition, $52.5 \%$ of our population reported minimum $30 \mathrm{~min}$ of exercise on at least 1 day of the week, while only $9 \%$ could perform the level of activity they recommend to their patients.

In conclusion, the number of publications per physician and time spent on social activities were higher in the current cohort as compared to figures reported in 2011. The proportion of cardiologists performing interventional cardiologic procedures varies according to physician preferences as well as the availability of adequate facilities. Majority of the cardiology specialists believed that there was a need for subspecialty training in fields such as interventional imaging and arrhythmia. We believe that the data obtained in this questionnaire-based survey may shed some light on the future policies on cardiology training. 

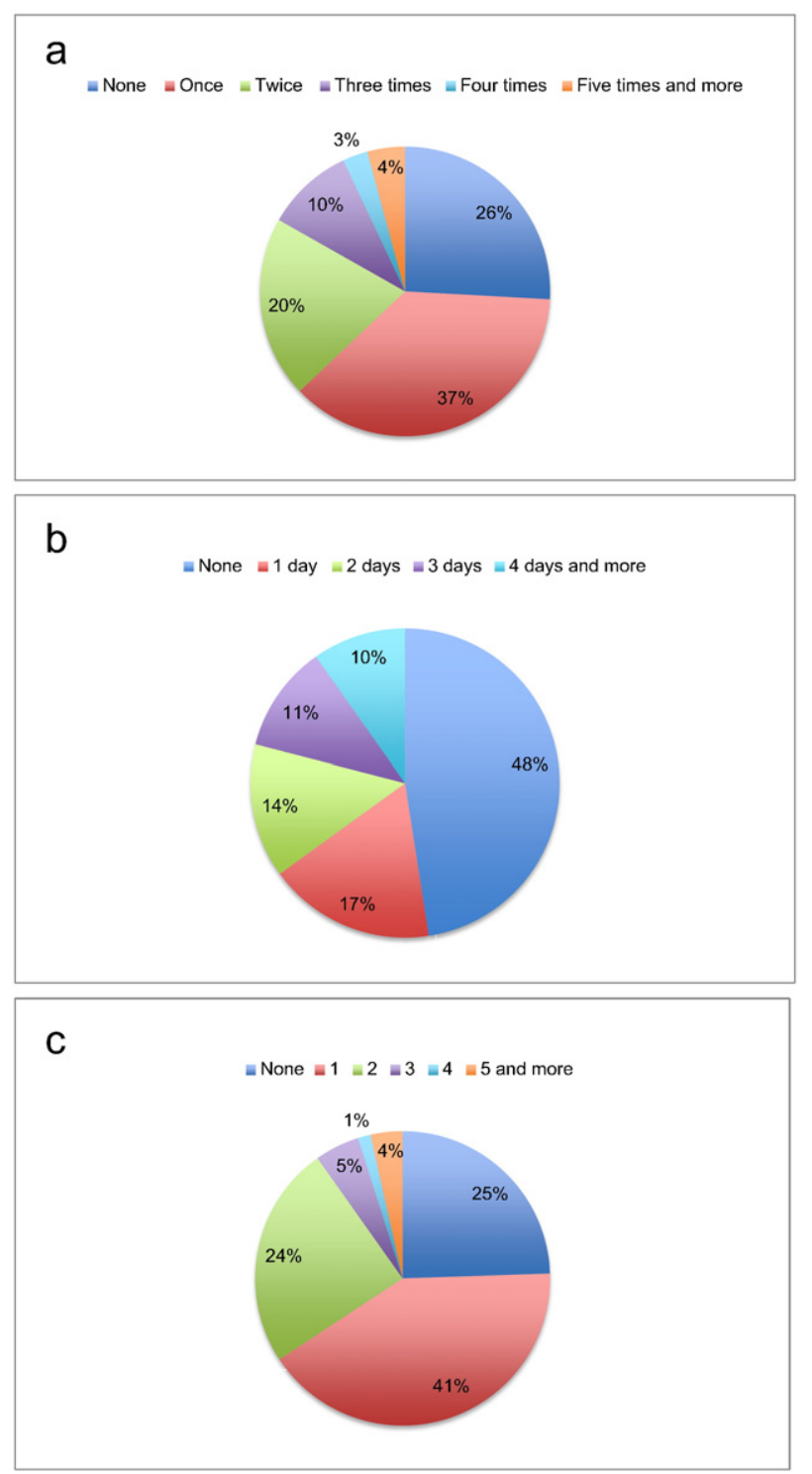

Fig. 1. Social life of cardiologists. a Monthly rates of cinema, theater and concert activities. b Rates of sporting events in a week. c Monthly rates of non-medical book reading.

\section{Limitations}

Small sample size represents the major limitation of our study. Secondly, the analysis of differences between the Eastern and Western cities of Turkey has not been identified.

\section{Conflict of interest}

On behalf of all authors, the corresponding author states that there is no conflict of interest.

\section{References}

1. WHO. The World Health Report 2002. Geneva: WHO/OMS; 2017.

2. Onat A, Şurdum Avcı G, Şenocak M, et al. Türkiye'de erişkinlerde kalp hastalığı ve risk faktörleri sıklığı taraması: 3. Kalp hastalıkları prevalansı. Turk Kardiyol Dern Ars 1991;19:26-33.

3. Devlet İstatistik Enstitüsü. Turkey in Statistics. 132; 2001 [Ankara].

4. Burke DT, DeVito MC, Schneider JC, Julien S, Judelson AL. Reading habits of physical medicine and rehabilitation resident physicians. Am J Phys Med Rehabil 2004;83 551-559.

5. Narasimhan S, Ranchord A, Weatherall M. International medical graduates' training needs: perceptions of New Zealand hospital staff. N Z Med J 2006;119:U2027.

6. Cohen JS, Patten S. Well-being in residency training: a survey examining resident physician satisfaction both within and outside of residency training and mental health in Alberta. BMC Med Educ 2005;5:21.

7. Levinson W, King Jr TE, Goldman L, Goroll AH, Kessler B. Clinical decisions. American Board of Internal Medicine Maintenance of Certification Program. N Engl J Med 2010;362:948-952.

8. Rodgers GP, Conti JB, Feinstein JA, et al. ACC 2009 survey results and recommendations: addressing the cardiology workforce crisis. J Am Coll Cardiol 2009;54: 1195-1208.

9. Poppas A, Cummings J, Dorbala S, Douglas PS, Foster E, Limacher MC. Survey results: a decade of change in professional life in cardiology: a 2008 report of the ACC women in cardiology council. J Am Coll Cardiol 2008;52:2215-2226.

10. Payzın Serdar, Altıntı̆̆ Ahmet, Can Levent, Akıllı Azem, Akın Mustafa, Kültürsay Hakan, Türkoğlu Cüneyt. Türkiye'de Invazif Kardiyoloji. Türk Kardiyol Dern Ars 1995;23:56-60.

11. Türkiye'de PTCA çalışmaları sempozyumu: 1. Ulusal İnvazif Kardiyoloji Kongresi. 1011 Haziran 1993, İstanbul.

12. Yıldız Bekir Serhat, Alkan Mustafa Beyazıt, Güngör Hasan, et al. A survey for the evaluation of the training period of cardiology specialists in Turkey. Anadolu Kardiyol Derg 2011;11:661-665. 